\title{
Linguistic and Cognitive Tactics of Representing Religious Ideas in Leo Tolstoy's Journalistic and Artistic Works
}

Tokarev Grigoriy Valeriyevich ${ }^{1}$

Professor, Tula State Lev Tolstoy Pedagogical University, Tula, Russia.

\section{Yahyapour Marzieh ${ }^{2}$}

Professor of Russian Language and Literature, Faculty of Foreign Languages and Literature, University of Tehran, Tehran, Iran.

(date of receiving: December, 2019; date of acceptance: March, 2020)

\begin{abstract}
The article deals with the linguistic and cognitive tactics of objectification of Leo Tolstoy's ideas on faith and religion. Keywords for categorizing these ideas are religion, faith, God, the church. Conceptualization tactics can be divided into scientific and common. On the one hand, the thinker provides a scientific basis for religion and, on the other, forms a personal understanding of God. In Tolstoy's worldview, these approaches are integrated. The linguistic and cognitive tactics of scientific conceptualization include etymologization, definition, metaphorization, and the tactics of naive conceptualization - a change in the interpretation of a traditional symbol, direct assessment, and open author's commentary. In the course of knowledge of religion, the writer identifies a number of features of this category: human submission to God, ensuring equality between people, meaningfulness, comprehensibility, and relevance. Its main function is a regulatory one. Tolstoy distinguishes the categories of religion and faith. The first tends to the outer beginning, the second - to the inner one. Both categories are related to the category of good. Faith is opposed to the church as a religious social institution. The leading means of presentation objectification is an indirect nomination. One of the tactics for expressing your understanding of religion and faith is to debunk existing stereotypes. Leo Tolstoy positions his point of view as the closest to the teaching of Christ.
\end{abstract}

Keywords: Religion, Faith, L.N. Tolstoy, Representation, Conceptualization, Categorization.

1. Email: grig72@mail.ru; ORCID: 0000-0002-2362-0902

2. E-mail: myahya@ut.ac.ir; ORCID: 0000-0001-8195-6909; Corresponding author. 


\section{Лингвокогнитивные тактики репрезентации религиозных представлений в публицистических и художественных произведениях Л.Н. Толстого}

\section{Токарев Григорий Валериевич ${ }^{1}$}

Профессор, Тульский государственный педагогический университет им. Л.Н. Толстого, Тула, Россия.

\section{Яхьяпур Марзие}

Профессор, Кафедра русского языка и литературы, Тегеранский университет, Тегеран, Иран.

(дата получения: декабрь 2019, дата принятия: март 2020)

\section{Аннотация}

В статье рассматриваются лингвокогнитивные тактики объективации представлений Л.Н. Толстого о вере и религии. Ключевыми словами категоризации данных представлений являются религия, вера, Бог, церковь. Тактики концептуализации можно разделить на научные и обыденные. С одной стороны, мыслитель даёт научное обоснование религии, с другой - формирует личностное понимание Бога. В мировоззрении Толстого эти подходы интегрируются. К лингвокогнитивным тактикам научной концептуализации можно отнести этимологизацию, дефинирование, метафоризацию, к тактикам наивной концептуализации - изменение интерпретанты традиционного символа, прямой оценочности и открытого авторского комментария.

В ходе познания религии писатель выделяет ряд признаков этой категории: подчинение человека Богу, обеспечение равенства между людьми, осмысленность, понятность, акциональность. Основная функция религии - регулятивная. Толстой различает категории религии и веры. Первая тяготеет к внешнему, вторая - к внутреннему началу. Обе категории соотносятся с категорией добра. Вера противопоставляется церкви как религиозному социальному институту. Ведущим средством объективации представления выступает косвенная номинация. Одной из тактик выражения своего понимания религии и веры является развенчание сложившихся стереотипов.

Свою точку зрения Толстой позиционирует как наиболее близкую к учению Христа.

Ключевые слова: Религия, Вера, Л.Н. Толстой, Представление, Концептуализация, Категоризация.

1. Email: grig72@mail.ru; ORCID: 0000-0002-2362-0902

2. Email: myahya@ut.ac.ir; ORCID: 0000-0001-8195-6909; Ответственный автор. 


\section{Введение}

Тема веры является ключевой для творчества Л.Н. Толстого. Она нашла своё воплощение как в художественном, так и публицистическом наследии писателя. Данная тема получает выражение с опорой на такие ключевые слова, как религия, вера, Бог, церковь.

Ю.И. Мирошников отмечает: «Сегодня, в 100-летнюю годовщину со дня его смерти, по-прежнему отсутствует определенность взглядов на то, кем его считать: язычником или христианином, позитивистом или романтиком, реакционером или революционером, анархистом или юродивым» (Мирошников 2010. 83).

Перевод Л.Н. Толстым евангелия, написание им трактата «Критика догматического богословия», отлучение от церкви зачастую трактуются как факты атеистического мировоззрения писателя. Такой подход является величайшим заблуждением: всю свою жизнь мыслитель стремился выстроить в соответствии с заповедями Христа, на протяжении всего своего творчества Толстой оставался религиозным писателем. Заметим, что особенности осмысления Л.Н. Толстым веры и религии осуществлялись преимущественно в философском и литературоведческом ключе. В данной статье речь пойдёт об особенностях концептуализации и категоризации представлений Л.Н. Толстого о религии и вере, то есть будет предпринята попытка лингвокогнитивной интерпретации мировоззрения писателя. В этом заключается научная новизна исследования.

Религиозное мировоззрение Л.Н. Толстого изучалось преимущественно в философском и этическом ключе. Фрагментарно, преимущественно на материале романа «Воскресенье» были рассмотрены особенности репрезентации концепта «Бог». Дискурсивный аспект, затрагивающий вопросы концептуализации и категоризации представлений Л.Н. Толстого о религии и вере в толстоведении пока остаётся белым пятном. 


\section{Основная часть}

Философские работы Л.Н. Толстого отражают научный, аргументированный подход к определению религии. Ясная интенция объяснить собственную концепцию религии / веры - отражена в заголовках произведений: «В чём моя вера?», «Что такое религия и в чём её сущность»). Толстой ведёт скрытую полемику как с людьми, отрицающими необходимость религии для современного человека, так и с теми, кто придерживается традиционной трактовки религии.

Изучая этимологию слова религия, писатель приходит к выводу, что этимон, указывающий на соединение, должен трактоваться как связь «человека с Богом» (Толстой 2006. Т.: 35: 161). Отношения этих категорий рассматриваются как партитивные: человек часть Бога. Этимология слова определяет особенности трактовки религии «...как установление человеком его отношения к бесконечному существу или существам, власть которых он чувствует над собой» (Там же. 162). Тем самым концептуализируется такой аспект религии, как подчинение человека.

Толстой отмечает, что такое понимание веры полностью отвечает учению Христа: «Кто поймёт своё отношение к хозяину, тот поймёт, что, только покоряясь воле хозяина, он может иметь жизнь, и будет знать, в чём его благо, и будет иметь веру, для которой не будет ничего невозможного. Вот этой-то вере и учит Христос. Вера, по учению Христа, заждется на разумном сознании смысла своей жизни» (Толстой 2006. Т.: 23: 409). Как видим, отношение к Богу, религии, вере Толстой моделирует с опорой на сценарий «хозяин слуга», что вскрывает важный аспект названных выше категорий - они подчиняют человека, влияют на его волю.

Установление данных отношений, по Л.Н. Толстому, имеет осознанный характер. Человек намеренно подчиняется этой силе, которая помогает ему правильно совершать поступки: «Истинная религия есть такое согласное с разумом и знаниями человека установленное им отношение к окружающей его 
бесконечной жизни, которое связывает его жизнь с этой бесконечностью руководит его поступками» (Толстой 2006. Т.: 35: 163). Толстой называет главные условия религии, одним из которых является равенство между людьми: «Всякая религия признаёт человека одинаково ничтожным перед бесконечностью, и потому всегда всякая религия включает понятие равенства всех людей перед тем, что она считает Богом... Так что признание равенства людей есть неизбежное, основное свойство всякой религии» (Там же. 164).

Основная функция религии, в понимании Толстого, - регулятивная: человек должен приумножать в себе божественное: «...Назначение же человека выводить практические правила из правила: поступать с другими, как хочешь, чтобы поступали с тобою...» (Там же. 191). Религия «...есть устанавливаемое, согласное с разумом и современными знаниями отношение человека к вечной жизни и к Богу, которое одно движет человечество вперёд к предназначенной ему цели...» (Там же. 198). Религия спасает человека, даёт ему ответы на нравственные вопросы: «Религия есть свод в одно согласное целое всех объяснений или ответов на те неизбежные и единственно интересные в жизни вопросы относительно жизни и смерти...» (Там же. 357). Характеризуя религиозные взгляды Л.Н. Толстого Г. Ореханов указывает: «...Главный признак церкви Л.Н. Толстого - её полная внеконфессиональность и безграничная открытость для членов, не связанных никакими исповедальными формулами. «Церковь» Л. Толстого определяется только верой в бога, отвечающей требованиям разума, и нравственным поведением, соответствующим Евангелию» (Ореханов 2016. 45).

Толстой смотрит на религию как на феномен человеческой культуры и приходит к выводу, что, пока будет существовать человечество, будет существовать религия: «...Религия всегда была и не может перестать быть необходимостью и неустранимым условием жизни разумного человека и разумного человечества» (Там же. 161). 
Толстой рассматривает религию и веру как смежные явления: религия имеет внешний характер, вера - внутренний. «Вера есть то же, что религия, с той только разницей, что под словом религия мы разумеем наблюдаемое во вне явление, верою же мы называем это же явление, испытываемое человеком в самом себе» (Там же. 171). Все признаки и функции религии спроецированы на веру. Как и религия, вера основана на условии её осознанности субъектом, отсюда вытекают такие её важные характеристики, как осмысленность и понятность: «Вера есть осознанное человеком отношение к бесконечному миру, из которого вытекает направление его деятельности. И потому истинная вера никогда не бывает неразумна, несогласна с существующими знаниями, и свойством её не может быть сверхъестественность и бессмысленность...» (Там же).

Вера акциональна: она проявляется в делах и поступках: «Вера ... есть то, что содействует делам, а дела - то, что совершает веру, т.е. то, что делает веру верою» (Толстой 2006. Т.: 23: 404), является «единственной причиной добрых дел. Добрые же дела суть неизбежные последствия веры» (Там же. 244). «Иаков говорит, что единственный признак веры - дела, вытекающие из неё, и что потому вера, из которой не вытекают дела, есть только слова, которыми как не накормишь никого, так и не сделаешь себя праведным и не спасёшься. И потому вера, из которой не вытекают дела, не есть вера. Это только желание верить во что-нибудь, это только ошибочное утверждение на словах, что я верю в то, во что я не верю». (Там же. 404). Этот аспект веры связывает её с категорией добра. Причём добро понимается не в отвлечённом, а в вполне конкретном смысле. «...Вера не то что неразлучна с добрыми делами, но вера есть единственная причина добрых дел. Добрые же дела суть неизбежные последствия веры. (Там же. 244). Нравственную основу понимания веры Л.Н. Толстым подчёркивает Е.Н. Чеснова: «Для Толстого характерно рассмотрение веры именно в сфере нравственности, где сам исследуемые феномен неотделим от религиозно-этических категорий» (Чеснова 2012. 83). 
В основе веры лежит осознание смысла жизни, предназначения человека. Это знание приобретается человеком путём исполнения воли Бога. «Основания веры есть смысл жизни, из которого вытекает оценка того, что важно и хорошо в жизни, и того что неважно и дурно. Оценка всех явлений жизни есть вера» (Толстой 2006. Т.: 23: 406). Бог же осмысляется Толстым как идеальное, как любовь, как «начало всего» (Толстой 2006. Т.: 35, 190). «...Бог есть дух, проявление которого живёт в нас, и силу которого мы можем увеличить своей жизнью...» (Там же. 192). Е.Г. Якимова и Е.Н. Чеснова отмечают: «Вера для Л.Н. Толстого это личная вера, личная связь, отношение с Богом» (Чеснова, Якимова 2014. 26).

Своё понимание религии / веры Толстой выражает с опорой на косвенную номинацию (Телия 1977. 129). Живые образы позволяют писателю не только ёмко выразить свои представления, но и вызвать перлокутивный эффект в сознании читателей.

Так, следствия из правила не противиться злому Толстой уподобляет открытию ключом замка. «Положение о непротивлении злому есть положение, связующее всё учение в одно целое, но только тогда, когда оно не есть изречение, а есть правило, обязательное для исполнения, когда оно есть закон. Оно есть точно ключ, отпирающий всё, но только тогда, когда ключ этот просунут до замка. Признание этого положения за изречение, невозможное к исполнению без сверхъестественной помощи, есть уничтожение всего учения» (Толстой 2006. Т.: 23, 315). Данная метафора вызывает аллюзии к образу закрытых ворот Царства Божия. Образ замка позволяет писателю выразить понимание того, что замок можно и не открыть, если неправильно воспользоваться ключом.

Толстой сопоставляет религию с живым организмом. Раскрывая позицию своих оппонентов, писатель сравнивает религию со слепой кишкой, отождествляет с болезнью, выделяя тем самым смыслы «ненужность», 
«вредность»: «...религия вообще отжила своё время и стала теперь не только бесполезным, но и вредным органом жизни обществ, вроде того, как слепая кишка в организме человека» (Толстой 2006. Т.: 35, 157). «Как бы болезнь, которую бывают одержимы некоторые люди и которую мы можем исследовать только по внешним симптомам» (Там же. 158).

Для выражения своей точки зрения Толстой прибегает к противоречащим образам. Образ живого организма позволяет подчеркнуть писателю идею внутренней жизни, движения религии: в своём развитии она проходит разные фазы. «После периода высшего развития религии всегда наступает период её ослабления и замирания, за которым следует обыкновенно период возрождения и установления более, чем прежнее, разумного и ясного религиозного учения». (Там же. 163).

Религия уподобляется главному жизнеобеспечивающему органу - сердцу: «Религия как была, так и остаётся ... сердцем жизни человеческих обществ, и без неё, как без сердца, не может быть разумной жизни» (Там же.).

Подчёркивая важность религии для человека, Толстой прибегает к метафорам вечного двигателя и огня: «...священный огонь религии, без которого не могла бы существовать жизнь человечества...» (Толстой 2006. Т.: $35,196)$.

Толстой отделяет истинную религию, веру от современной ему церкви, более того он противопоставляет эти явления. «Религиозные взгляды писателя не совпадали с принятыми и принимаемыми условностями государства, общества, официальной церкви» (Амирханян 2010. 33). Церковь, по мнению писателя, отступает от заповедей Христа и искажает их, превращаясь в своего рода караульщика: «Все церкви - католическая, православная и протестантская - похожи на караульщиков, которые заботливо караулят пленника...» (Толстой 2006. Т.: 23, 441). Церковь отнимает свободу, запугивая человека непонятными обрядами. 
Свою религиозную концепцию в художественно форме Л.Н. Толстой выражает в последнем романе «Воскресение», написанном в 1889-1899 годах. Как указывает А.Н. Денисов: «Произведение явилось одним из образцов радикальной Толстовской постановки вопроса о христианской культуре» (Денисов 2014. 318). Тема веры является магистральной в этом произведении. Заголовок текста и прогнозируемая последующая интерпретация его читателем нацелена на экспликацию авторской религиозной концепции - веры для человека в существующем, дольнем мире. Воскресение возможно в этой жизни и осуществимо в случае нравственной работы над самим собой. Ю.И. Мирошников указывает: «Толстой раз и навсегда отринул от себя утверждение христианства о том, что физическая смерть не является окончательной смертью личности. Он испытывал радикальное сомнение не только в возможности воскресения умерших земной смертью последователей Христа, но и воскресения самого Сына Божьего, которого Лев Николаевич признал лишь сыном человеческим. ... Коренная нравственная трансформация человека, фактически эквивалентная его спасению...» (Мирошников 2010. $105)$.

Можно считать, что роман Толстого построен на развенчании общепринятой идеологии христианства и разъяснения собственных взглядов писателя. Для реализации данной коммуникативной задачи Толстой в романе неоднократно обращается к изображению религиозных обрядов. Так, в восьмой главе описывается обряд приведения к присяге заседателей перед началом судебного процесса. Толстой использует технику коллажа, сочетая лексемы религиозного и бытового дискурсов. Потенциал первых заключается в создании эффекта торжественности и сакральности, вторых приземлённости. В результате такого лексического словоупотребления возникает эффект неоправданного ожидания, разрушения стереотипного, традиционного знания. Священник и при этом старичок «с опухшим, желто- 
бледным лицом», в рясе и с опухшими, тяжело передвигаемыми ногами, с крестом на груди и «каким-то маленьким орденом». Толстой меняет ожидаемую стратегию восприятия смысла слова. Так, глагол священствовать в качестве результатов предполагает нравственное улучшения человека, однако контекст указывает на иные, материальные следствия: «собирался через три года отпраздновать свой юбилей», «он продолжал трудиться на благо церкви, отечества и семьи, которой он оставит, кроме дома, капитал не менее тридцати тысяч в процентных бумагах», «теперь он не без удовольствия познакомился с знаменитым адвокатом, внушавшим ему большое уважение тем, что за одно только дело старушки с огромными цветами на шляпке он получил десять тысяч рублей» (Толстой 2006. Т.: 32, 29). Из чего следует отождествление священнодействования с другими, материальными практиками, приносящими доход.

Толстой использует тактику экспликации своих интенций через прямые суждения: «труд его в суде, состоящий в том, чтобы приводить людей к присяге над Евангелием, в котором прямо запрещена присяга», употребления оценочной лексики: «то же, что, был труд нехороший, никогда не приходило ему в голову» (Там же. 28), конструирования дисфемистичных перифразов: «в насаленную дыру епитрахили» (Там же. 29).

В обряде приведения к присяге священника волнуют внешние составляющие: «Правую руку поднимите, а персты сложите так вот ... Не опускайте руки, держите так...» (Там же.). Толстой подчёркивает бесполезность данного обряда: «Всем было неловко, один только старичок священник был, несомненно, убежден, что он делает очень полезное и важное дело» (Там же.).

Моральную неправомерность суда Толстой показывает путём нестыковки представлений о нравственной роли заседателей с их реальным моральным обликом: «Присяжные встали и, теснясь, прошлись в совещательную комнату, 
где почти все они тотчас достали папиросы и стали курить», «Купец, распространяя вокруг себя запах вина и удерживая шумную отрыжку, на каждую фразу одобрительно кивал головою» (Там же.).

Кульминацией в развенчании традиционных представлений о христианском богослужении выступает 39-я глава романа. Для описания обряда Толстой избирает позицию обычного человека. Для этого писатель прибегает к приёму погружения системы символов христианской картины мира в обыденную систему ценностей, то есть для интерпретации знаков одной системы использует другой интерпретационный код. Итогом применения такого когнитивного приёма становится непонимание, отсутствие интереса, ирония и цинизм. Такую презентацию материала назвал «уничтожающей», «разоблачительной» сатирой (Васильев 2016. 19).

В тексте неоднократно повторяются слова, указывающие на непонимание обычным человеком происходящего: «славянские, сами по себе мало понятные, а еще менее от быстрого чтения и пения понятные молитвы», «таким странным, напряженным голосом, что ничего нельзя было понять» (Толстой 2006. Т.: 32, 134). В тексте отражена наивная интерпретанта (Моррис 1982. 40) символов религиозного кода, что создаёт комический эффект: «вырезывал и раскладывал кусочки хлеба на блюдце и потом клал их в чашу с вином, произнося при этом различные имена и молитвы», «хор торжественно запел, что очень хорошо прославлять родившую Христа без нарушения девства девицу Марию, которая удостоена за это большей чести, чем какие-то херувимы, и большей славы, чем какие-то серафимы» (Толстой 2006. Т.: 32, 134). Приём включения символа в иную дискурсивную сферу приводит к формированию профанной, алогичной интерпретации: «...сказано было, как Христос, воскресши, прежде чем улететь на небо и сесть по правую руку своего Отца, явился сначала Марии Магдалине, из которой Он изгнал семь бесов, и потом одиннадцати ученикам, и как велел им проповедовать 
Евангелие всей твари, причем объявил, что тот, кто не поверит, погибнет, кто же поверит и будет креститься, будет спасен и, кроме того, будет изгонять бесов, будет излечивать людей от болезни наложением на них рук, будет говорить новыми языками, будет брать змей, и если выпьет яд, то не умрет, а останется здоровым...»; «предполагалось, что вырезанные священником кусочки и положенные в вино, при известных манипуляциях и молитвах, превращаются в тело и кровь Бога. Манипуляции эти состояли в том, что священник равномерно, несмотря на то, что этому мешал надетый на него парчовый мешок, поднимал обе руки кверху и держал их так, потом опускался на колени и целовал стол и то, что было на нем. Самое же главное действие было то, когда священник, взяв обеими руками салфетку, равномерно и плавно махал ею над блюдцем и золотой чашей. Предполагалось, что в это самое время из хлеба и вина делается тело и кровь, и потому это место богослужения было обставлено особенной торжественностью», ««Изрядно о Пресвятей, Пречистой и Преблагословенней Богородице», - громко закричал после этого священник из-за перегородки, и После этого считалось, что превращение совершилось, и священник, сняв салфетку с блюдца, разрезал серединный кусочек начетверо и положил его сначала в вино, а потом в рот..» (Там же. 135).

Десакрализация семантики символа осуществляется за счёт употребления бытовизмов, заменяющих религиозную номинацию: «...этому мешал надетый на него парчовый мешок...», «...священник унес чашку за перегородку...», «выкованное золоченое изображение ...Бога» (Там же. 136), необычного словоупотребления, изменения традиционного контекстного окружения: «пригласил желающих тоже поесть тела и крови Бога, находившихся в чашке», «дьячок тут же, отирая рты детям, веселым голосом пел песню о том, что дети едят тело Бога и пьют Его кровь», «став перед предполагаемым выкованным золоченым изображением (с черным лицом и черными руками) того самого Бога, которого он ел» (Там же.). 
При реализации стратегии дискредитации традиционных стереотипов Толстой использует приём аллюзии. Так, фрагмент молитвы, в каждой фразе которой упоминается имя господа, апеллирует к заповеди Христа не упоминать имя господа: «Иисусе Сладчайший, апостолов славо, Иисусе мой, похвала мучеников, Владыко всесильне, Иисусе, спаси мя, Иисусе Спасе мой, Иисусе мой Краснейший, к тебе притекающего, Спасе Иисусе, помилуй мя, молитвами рождшия тя, всех, Иисусе, святых Твоих, пророк же всех, Спасе мой Иисусе, и сладости райския сподоби, Иисусе человеколюбче!» (Там же.).

Толстой разными способами демонстрирует отчуждённость ритуала от духовного мира человека:

«Содержание молитв заключалось преимущественно в желании благоденствия государя императора и его семейства»..., «священник, разговаривая со смотрителем, совал крест и свою руку в рот, а иногда в нос подходившим к нему арестантам, арестанты же старались поцеловать и крест и руку священника. Так кончилось хрис тианское богослужение, совершаемое для утешения и назидания заблудших братьев...» (Там же. 137).

Саркастический эффект, названный В.В. Лагно стилеобразующим средством романа (Лагно 2017. 53), создаёт употребление контекстуальных антонимов (Новиков, 1973): богослужение идёт на фоне позвякивания кандалов, символизирующих неравенство и несвободу («...особенно часто забренчали кандалы...» (Толстой 2006. Т.: 32, 136)).

Резюмируя, отметим, что Толстой не только смог продемонстрировать несостоятельность традиционных стереотипов, но и воздействовать на читателя, используя различные приёмы работы со словом, дискурсом, образом, художественной деталью. 
Стремление писателя к точности, ясности, последовательности изложения своих идей даже в художественном тексте объясняет использование приёма включения авторского комментария в повествование, что выводит художественный текст на границу с публицистикой. Толстой в эксплицитной форме выражает свои идеи. Предвидя обвинения в кощунстве и святотатстве, он выступает не против Христа, а против искажения его идей: «тот самый Иисус, имя которого со свистом такое бесчисленное число раз повторял священник, всякими странными словами восхваляя его, запретил именно все то, что делалось здесь» (Толстой 2006. Т.: 32, 137). В «Воскресении» Толстой ратует за возвращение к истинной Христовой вере и жизни по заповедям Евангелия, возвращает всем реалиям бытия их исконный христианский смысл...» (Масолова 2012. 72). Толстой против замены истинного обращения к богу поклонению непонятным символам и следованию чуждым ритуалам. Писатель прибегает к прямой негативной оценке религиозной традиции: «бессмысленное многоглаголание и кощунственное волхвование священников-учителей» (Толстой 2006. Т.: 32, 137). Он напоминает забытые людьми заветы Христа: «запретил одним людям называть учителями других людей, запретил молитвы в храмах, а велел молиться каждому в уединении, запретил самые храмы, сказав, что пришел разрушить их и что молиться надо не в храмах, а в духе и истине; главное же, запретил не только судить людей и держать их в заточении, мучать, позорить, казнить, как это делалось здесь, а запретил всякое насилие над людьми, сказав, что он пришел выпустить плененных на свободу» (Там же.).

Толстой пытается дать иную интерпретацию базовым символам христианства: так крест он трактует как виселицу, на которой был распят Христос: «золоченый крест с эмалевыми медальончиками на концах, который вынес священник и давал целовать людям, был не что иное, как изображение той виселицы, на которой был казнен Христос» (Там же.). 
Толстой объясняет слепое следование христианским ритуалам люди
повинуются установившемуся правилу: «надо верить в эту веру». Священствование стало доходным делом и позволяет человеку кормить свою семью: «Так же верил и дьячок и еще тверже, чем священник, потому что совсем забыл сущность догматов этой веры, а знал только, что за теплоту, за поминание, за часы, за молебен простой и за молебен с акафистом, за все есть определенная цена, которую настоящие христиане охотно платят» (Там же. 138).

Толстой называет существующие ритуалы обманом, в который люди сами погружаются с целью получить «удобства» в реальной и загробной жизни: «Хотя большинство из них, проделав несколько опытов приобретения удобств в этой жизни посредством молитв, молебнов, свечей, и не получило их, молитвы их остались неисполненными, - каждый был твердо уверен, что эта неудача случайная и что это учреждение, одобряемое учеными людьми и митрополитами, есть все-таки учреждение очень важное и которое необходимо если не для этой, то для будущей жизни» (Там же.).

Е.Н. Чеснова и Е.Г. Якимова отмечают: «Понимание Л.Н. Толстым Бога, связи человека с Ним, отношение к культовой практике предвосхитило популярную сейчас концепцию личного Бога, отход и неприятие современным человеком культовой практики, постулирование личной связи с Богом. (Чеснова, Якимова 2014. 24).

\section{Заключение}

Таким образом, свою концепцию веры Толстой выстраивает отдельно от церковной.

Писатель подчёркивает, что старается своё понимание веры максимально приблизить к учению Христа. Основное различие религии и веры заключается в том, что религия имеет внешнее выражение, а вера - внутреннее. Вера 
действенна, осмыслена, принята субъектом, а поэтому является выражением его воли, понятна ему. Этим вера отличается от суеверия, которое навязывает человеку церковь. Акциональный аспект веры основывается на осознании смысла жизни, на золотом правиле этики и непротивлении злу насилием. Характерно, что в публицистическом и художественном тексте Толстой использует разные лингвокогнитивные тактики презентации знания. Для публицистического текста характерны этимологизация, дефинирование, метафоризация. Для художественного стратегия дискредитации, выражаемая в изменении интерпретанты традиционного символа за его погружения в иную дискурсивную среду, а также тактика оценочности и открытого авторского комментария.

\section{Литература}

1- Амирханян А.М. (2010). Евангельские изречения в романе Л.Н. Толстого «Воскресение» // Филологические науки. № 1. С. 31-41.

2- Васильев С.А. (2016). «...Одно из самых светлых и сильных воспоминаний» (образ пасхального богослужения в романе Л.Н. Толстого «Воскресение») // Вестник МГПУ. Серия Филология. Теория языка. Языковое образование. № 2 (22). C. 18-24.

3- Денисов А.Н. (2014). Евангельская аллюзия в романе Л.Н. Толстого «Воскресение» // Наследие Л.Н. Толстого в гуманитарных парадигмах современной науки. Материалы 34-х Международных Толстовских чтений. Тула. С. 315-320.

4- Лагно (2017). Функиии сатиры и иронии в романе Л.Н. Толстого «Воскресение» // Научный диалог: молодой учёный. Москва. Изд-во «Общественная наука». С. 53-55.

5- Масолова Е.А. (2012). Мифопоэтическая образность романа Л.Н. Толстого «Воскресение» // Культура и текст. № 1(13). С. 62-72.

6- Мирошников Ю.И. (2010). Романтическое мировоззрение Л.Н. Толстого как интегральная характеристика его художественного и философскорелигиозного творчества // Научный ежегодник Института философии и права Уральского отделения Российской академии наук. Вып. 10 С. 87-103.

7- Моррис Ч.У. (1983). Основания теории знаков // Семиотика. Москва. Изд-во «Радуга». С.37-89. 
8- Новиков Л.А. (1973). Антонимия в русском языке (семантический анализ противоположности в лексике). Москва. Изд-во «Моск. гос. ун-та».

9- Ореханов Г., прот. (2016). Л.Н. Толстой как религиозный тип (интерконфессиональный аспект вопроса) // Вопросы философии. - № 4. С. 42-53.

10- Телия В.Н. (1977). Вторичная номинация и её виды // Языковая номинация: Виды наименований. Москва. Изд-во «Наука». С. 129-221.

11- Толстой Л.Н. (2006). Определение религии-веры / Л.Н. Толстой // Полное собрание сочинений: в 90 т. Тт. 17, 23, 32, 35. Москва. Изд-во «РГБ».

12- Чеснова Е.Н. (2012). Осмысление феномена веры в религиозно-нравственном учении Л.Н. Толстого // Гуманитарные ведомости ТГПУ им. Л.Н. Толстого.№ 3. C. $82-86$.

13- Чеснова Е.Н., Якимова Е.Г. (2014). Философия веры и эсхатологические «предчувствия» в учении Л.Н. Толстого // Гуманитарные ведомости ТГПУ им. Л.Н. Толстого. № 3. С. 24-36.

\section{Bibliography}

1- Amirhanjan A.M. (2010). Evangel'skie izrechenija v romane L.N. Tolstogo «Voskresenie» // Filologicheskie nauki. № 1. S. 31-41.

2- Vasil'ev S.A. (2016). "...Odno iz samyh svetlyh i sil'nyh vospominanij» (obraz pashal'nogo bogosluzhenija $v$ romane L.N. Tolstogo "Voskresenie») // Vestnik MGPU. Serija Filologija. Teorija jazyka. Jazykovoe obrazovanie. № 2 (22). S. 18 24.

3- Denisov A.N. (2014). Evangel'skaja alljuzija v romane L.N. Tolstogo «Voskresenie» // Nasledie L.N. Tolstogo v gumanitarnyh paradigmah sovremennoj nauki. Materialy 34-h Mezhdunarodnyh Tolstovskih chtenij. Tula. S. 315-320.

4- Lagno (2017). Funkcii satiry i ironii v romane L.N. Tolstogo «Voskresenie»// Nauchnyj dialog: molodoj uchjonyj. Moskva. Izd-vo «Obshhestvennaja nauka». S. 53-55.

5- Masolova E.A. (2012). Mifopojeticheskaja obraznost' romana L.N. Tolstogo «Voskresenie» // Kul'tura i tekst. № 1(13). S. 62-72.

6- Miroshnikov Ju.I. (2010). Romanticheskoe mirovozzrenie L.N. Tolstogo kak integral'naja harakteristika ego hudozhestvennogo $i$ filosofsko-religioznogo tvorchestva // Nauchnyj ezhegodnik Instituta filosofii i prava Ural'skogo otdelenija Rossijskoj akademii nauk. Vyp. 10 S. 87-103.

7- Morris Ch.U. (1983). Osnovanija teorii znakov // Semiotika. Moskva. Izd-vo «Raduga». S.37-89.

8- Novikov L.A. (1973). Antonimija v russkom jazyke (semanticheskij analiz protivopolozhnosti v leksike). Moskva. Izd-vo «Mosk. gos. un-ta». 
9- Orehanov G., prot. (2016). L.N. Tolstoj kak religioznyj tip (interkonfessional'nyj aspekt voprosa) // Voprosy filosofii. - № 4. S. 42-53.

10- Telija V.N. (1977). Vtorichnaja nominacija $i$ ejo vidy // Jazykovaja nominacija: Vidy naimenovanij. Moskva. Izd-vo «Nauka». S. 129-221.

11- Tolstoj L.N. (2006). Opredelenie religii-very / L.N. Tolstoj // Polnoe sobranie sochinenij: v 90 t. Tt. 17, 23, 32, 35. Moskva. Izd-vo «RGB».

12- Chesnova E.N. (2012). Osmyslenie fenomena very $v$ religiozno-nravstvennom uchenii L.N. Tolstogo // Gumanitarnye vedomosti TGPU im. L.N. Tolstogo. - № 3. S. 82-86.

13- Chesnova E.N., Jakimova E.G. (2014). Filosofija very $i$ jeshatologicheskie "predchuvstvija»v uchenii L.N. Tolstogo // Gumanitarnye vedomosti TGPU im. L.N. Tolstogo. № 3. S. 24-36.

\section{HOW TO CITE THIS ARTICLE}

Токарев Г. В., Яхьяпур М. (2020). Linguistic and Cognitive

Tactics of Representing Religious Ideas in Leo Tolstoy's

Journalistic and Artistic Works. Issledovatel'skiy Zhurnal Russkogo Yazyka i Literatury, 8(2), 87-105.

DOI: $10.29252 /$ iarll.16.87

URL: http://journaliarll.ir/index.php/iarll/article/view/105

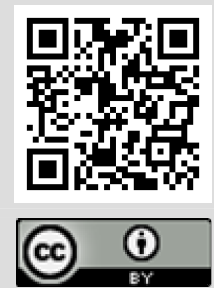




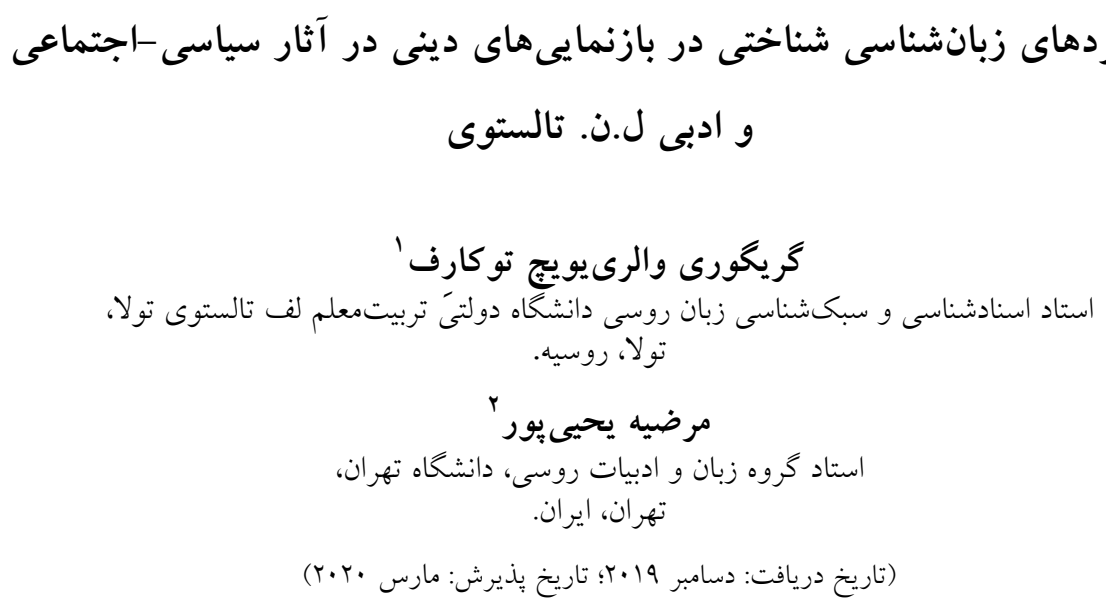

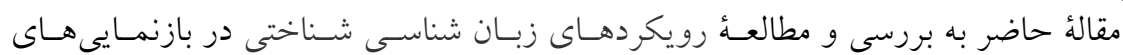

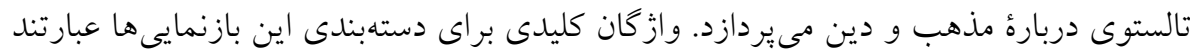

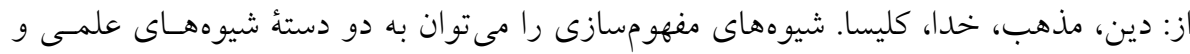

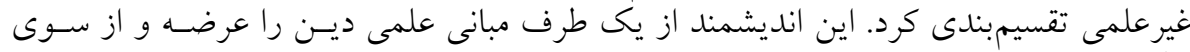

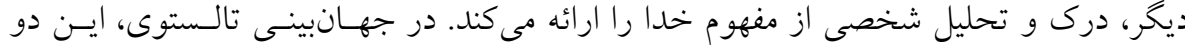

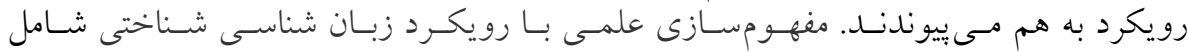

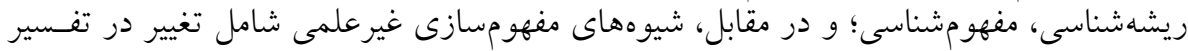

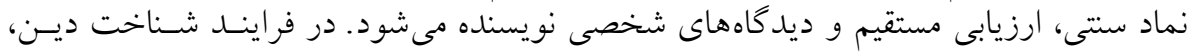

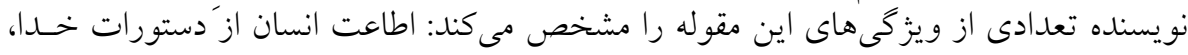

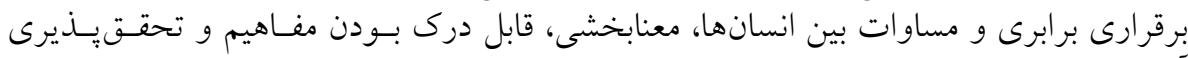

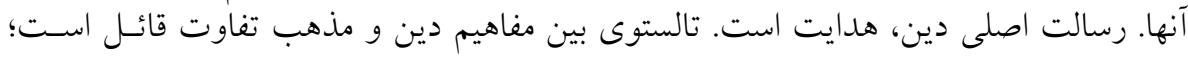

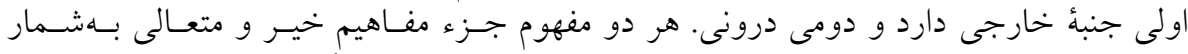

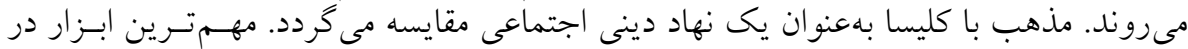

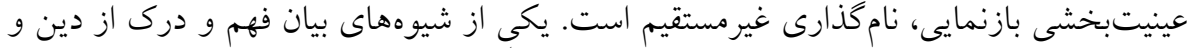

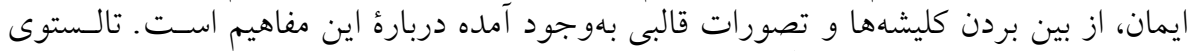

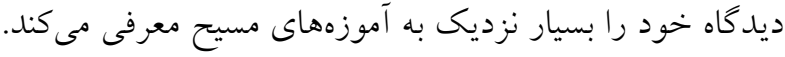
وازگًان كليدى: دين، مذهب، ل.ن. تالستوى، بازنمايى، مفهومسازى، دستهبندى.

1. Email: grig72@mail.ru; ORCID: 0000-0002-2362-0902

2. Email: myahya@ut.ac.ir; ORCID:0000-0001-8195-6909 (نويسنده مسئول) 